\title{
The Political Sources of Systematic Investment Risk: Lessons from a Consensus Democracy
}

\author{
Journal Article \\ Author(s): \\ Bechtel, Michael M. \\ Publication date: \\ 2009-04 \\ Permanent link: \\ https://doi.org/10.3929/ethz-a-006032090 \\ Rights / license: \\ In Copyright - Non-Commercial Use Permitted \\ Originally published in: \\ The Journal of Politics 71(2), https://doi.org/10.1017/S0022381609090525
}




\title{
The Political Sources of Systematic Investment Risk: Lessons from a Consensus Democracy
}

\author{
Michael M. Bechtel ETH Zurich (Swiss Federal Institute of Technology)
}

\begin{abstract}
This study examines the relationships between democratic politics and systematic investment (or capital) risk. Low risk is crucial to any well-functioning economy, as it encourages capital investment, facilitates growth, and enhances overall economic performance. This article distinguishes preelectoral, postelectoral, and institutional factors and examines how these influence systematic investment risk using daily stock market data from Germany. The results suggest that more (less) favorable and reliable investment conditions during the incumbency of right (left)-leaning governments lead to lower (higher) investment risk. This partisan effect is stronger the more inflation increases and depends on whether government is unified or divided. Investors also anticipate the effect of government partisanship: systematic risk decreases (increases) if the electoral prospects of a right (left)-leaning government enhance. Finally, grand coalition governments as well as periods of coalition formation trigger higher investment risk.
\end{abstract}

T here has been an astonishing increase in the flow of international capital. Daily transactions made on global stock markets in 1996 amounted to 61 billion dollars. In 2006, average turnover was worth more than 278 billion dollars on a single day. ${ }^{1}$ Along with this rapid increase in international capital flows, countries nowadays compete for capital investment on a global scale, as economic actors can-within just a few seconds-move their money among financial markets all over the world. Against this background it does not come as a surprise that political scientists are increasingly interested in which and how political factors influence the performance of financial markets (Bernhard and Leblang 2006; Freeman, Hays, and Stix 2000; Herron 2000; Roberts 1990). While most of these studies have looked into the effects of partisan politics on stock market returns, less effort has been devoted to analyzing what can reasonably be called a key factor for investment attractiveness: systematic investment (or capital) risk. This lack of scholarly attention is all the more significant, since low systematic (or countryspecific) investment risk is crucial to shareholders, firms, and overall economic performance. It not only affects investment (Wadhwani 1986), but also consumption, exchange rates (Bachman 1992), growth
(Kamara 1997), and wealth (Demirgüç-Kunt and Levine 1996; Levine and Zervos 1998).

Despite its importance for a country's economic performance, little is known about the relationships between democratic politics and investment risk. However, as Mancur Olson has already argued when pointing out the economic advantages of democracies as compared to dictatorships, political predictability may be crucial in order to create an environment beneficial for investment and growth, which is why "there are colossal gains from providing domestic tranquility" $(1993,567)$. Yet, investment conditions not only vary across democracies and autocracies (Mubarak 2005; Quinn and Woolley 2001), but also within democratic systems. By making use of the possibility to isolate systematic investment risk, this analysis disentangles and estimates the (rival) effects of a large set of preelectoral, postelectoral, and institutional factors.

This article extends the rational partisan model of government (Alesina, Roubini, and Cohen 1997; Hibbs 1977) in that parties are not only assumed to pursue different economic policies. They also vary with regard to the predictability of these policies. This is because parties differ in their ability to design and effectively implement economic policies and the reliability with which they tackle shocks adverse to

\footnotetext{
${ }^{1}$ Source: World Federation of Exchanges.

The Journal of Politics, Vol. 71, No. 2, April 2009, Pp. 661-677

(C) 2009 Southern Political Science Association
}

doi:10.1017/S0022381609090525

ISSN 0022-3816 
capital invested in a country by taking beneficial and skillful policy responses. As right-leaning parties provide more favorable and reliable investment conditions, this is reflected by a decrease in a country's level of systematic capital risk. Second, the theory suggests that divided government plays an important role for systematic investment risk as well. Under divided government policy changes require the consent of government and opposition parties, which makes it difficult to forecast policy outcomes and is likely to result in policy gridlock. Therefore, the ability of an incumbent to implement its ideal policy and to quickly react to economic shocks harmful to capital markets is strongly reduced (Krehbiel 1998; Roubini and Sachs 1989). Such reasoning suggests that while partisan effects on investment uncertainty do exist, they are moderated by partisan conflict between the executive and the legislative branches. Third, periods of coalition formation and grand coalition governments should increase policy uncertainty and thereby trigger higher systematic investment risk.

The evidence based on daily stock market data from Germany supports these claims. The estimations suggest that systematic risk decreases by about 1.5 to 2 percentage points on average when a right-leaning government is installed and enjoys unified government. This partisan effect is less pronounced under divided government. The results also emphasize the importance of rational expectations about government partisanship. Uncertainty on the financial marketplace decreases by about 1.4 percentage points on average if a right-leaning coalition is becoming more likely to win the upcoming election. In addition, systematic risk is higher during times of coalition formation and in periods of grand coalition governments.

There are several reasons for why political determinants of investment risk in Germany are particularly interesting to study. Not only are German financial markets among the most important in the world, it is also the largest economy in the European Union and one of the weightiest member states politically. Moreover, Germany is one of the world's major economies and a key trading partner for the United States. With regard to the variation which can be exploited for evaluating the hypotheses put forward in this paper, Germany presents an ideal case. First, due to its consensual political system (Lijphart 1999), Germany reflects the richness of democratic politics: it features different types of long-ruling coalition governments, which is important, because the impact of government partisanship can only fully emerge if governments remain unchanged over several years (Blais, Blake, and Dion 1993). As time is needed to affect economic policy, long-ruling governments facilitate the identification of partisan effects. Second, within the time frame studied, Germany exhibits periods of divided as well as unified government along with complete alternation in government partisanship - a phenomenon which is rare in the universe of democratic countries. ${ }^{2}$ Even if only a minority of the hypotheses about the relevance of democratic politics for investment risk are correct, scholarship which focuses exclusively on the United States may miss some of the most interesting variation in political factors which affect uncertainty on financial markets. Therefore, Germany provides an ideal testing ground for evaluating the full range of preelectoral, postelectoral, and institutional effects and thus helps to overcome the limitations of prior research that has almost exclusively focused on the United States.

The remainder of this paper is organized as follows. The next section briefly presents the market-micro foundation which motivates this analysis. The following section derives hypotheses about the impact of politics on systematic investment risk. The fourth section introduces the data and presents the results along with several robustness checks. The final section summarizes the findings and proposes avenues for further research.

\section{Investment Decisions and Capital Risk}

Actors on financial markets are interested in maximizing the value of their capital investment. In a world of ever fewer restrictions on international capital flows, actors are free to choose in which country's financial market to invest or from which market to withdraw their money. Such capital (re-)allocation decisions are obviously of great importance for a country's economy: capital is needed to finance growth, which affects consumption, and wealth. In order to understand when investors decide to invest in or disinvest from a country's capital market and to motivate the subsequent analysis of the political sources

\footnotetext{
${ }^{2}$ Moreover, as the chosen period offers all the variation needed to estimate the effects of a wide array of political factors on systematic capital risk, the time frame studied (1991-2005) can be kept at a reasonable size, which reduces the danger of case heterogeneity and structural breaks confounding the results.
} 
of systematic investment risk, one needs to ask which parameters guide investor behavior. Markowitz's (1959) portfolio selection theory provides a very general and helpful framework for analyzing investors' capital allocation decisions. This theory specifies how investors construct a portfolio that optimally diversifies risk.

According to standard portfolio theory, the value $V_{Q}$ of a portfolio $Q$ is related to both, the expected return $\mu_{Q}$ and the standard deviation $\sigma_{Q}$ of $Q . \sigma_{Q}$ indicates how strongly the return deviates on average from its mean value, which is why the standard deviation of $\mu_{Q}$ is commonly referred to as the risk associated with portfolio Q (Elliott and Kopp 2005, 316-18). An investor maximizes his utility by choosing a portfolio which maximizes $V_{Q}\left(\mu_{Q}, \sigma_{Q}\right)$, i.e., he creates a portfolio consisting of a finite number of securities which—-taken together-result in the highest portfolio return for a given level of risk or exhibits the lowest level of risk for a given expected return. A portfolio which satisfies either of the two conditions is called efficient. The standard functional form of $V_{Q}$ is given by

$$
V_{Q}=\gamma \mu_{Q}-\sigma_{Q}
$$

where $\gamma \geq 0$ is a weighting factor indicating how much an investor cares about taking into account $\mu_{Q}$ when constructing the efficient portfolio. Within this general framework, the capital asset pricing model (CAPM) (Lintner 1965; Mossin 1966; Sharpe 1964) assists in determining the expected return and the return standard deviation of an asset in equilibrium.

The CAPM uses the notion of a market portfolio, $m$, which is the sum of all value-weighted securities traded on c's market. Therefore, in this market portfolio all idiosyncratic risk sources (e.g., firm- or industry-specific actions or economic and political events) associated with securities of $c$ 's market, which increase the probability of the realized return deviating from what one would expect, are completely diversified. Now suppose an investor considers investing in a security $i$ in country $c$. Then, according to the CAPM, the expected return of security $i, E\left(r_{i}^{c}\right)$, is given by the following linear function:

$$
E\left(r_{i}^{c}\right)=r_{f}+\left(E\left(r_{m}^{c}\right)-r_{f}\right) \beta_{i}^{c},
$$

where $r_{f}$ is the risk-free rate, $E\left(r_{m}^{c}\right)$ is the expected return on $c^{\prime}$ s overall market and $\beta_{i}^{c}$ is the sensitivity of $E\left(r_{i}^{c}\right)$ to changes in the (excess) return on the market portfolio. The market sensitivity $\beta_{i}^{c}$ is the market risk of security $i$ in country $c$, while $\left(E\left(r_{m}^{c}\right)-r_{f}\right) \beta_{i}^{c}$ is the risk premium. Thus, according to equation (2) the expected return is the sum of the risk-free rate and the risk premium.

Despite its simplicity, the CAPM provides valuable analytical leverage. The model posits that a portfolio comprises two types of risk. The first type is unsystematic (specific or idiosyncratic) risk. Unsystematic risk does not pose a problem to an investor interested in minimizing risk, because it can be diversified away by constructing a portfolio in which idiosyncratic risk associated with different securities in $c$ cancel each other out. Thus, since in a large market which offers a wide array of different assets specific risk can be diversified, for an investor there is no need to accept unsystematic risk. Empirically, for large markets such as in the United States, the United Kingdom, or Germany, a portfolio of 30 assets is enough to eliminate unsystematic risk. This renders the portfolio sufficiently diversified to limit exposure to systematic risk only.

However, things look very different when it comes to systematic risk. Can an investor get rid of systematic risk? The answer is no, and the reason is straightforward: Systematic risk refers to uncertainty common to all assets in country $c$ which are fraught with risk. Therefore, while unsystematic risk simply plays no role in determining the expected return and is thus inconsequential for optimizing investors, whenever an investor creates a portfolio of assets from c's market, the minimum level of risk to take is the level of systematic risk.

Knowing that no actor interested in investing in $c$ needs to accept more than systematic risk, it is possible to examine which factors drive the minimum level of riskiness of any portfolio consisting of investments in $c$ 's capital markets. Recall that by definition in equilibrium every security fraught with risk is represented in the market portfolio according to its relative market value. Therefore, the value of a portfolio can be related to the performance of the overall market. Suppose without loss of generality a portfolio $Q$ consisting of $a$ shares of security $i$ and $1-a$ shares of $c$ 's market portfolio. Then, the return of this portfolio is given by

$$
\mu_{Q}=a E\left(r_{i}^{c}\right)+(1-a) E\left(r_{m}^{c}\right),
$$

and the corresponding standard deviation is given by

$$
\begin{aligned}
\sigma_{Q}= & {\left[\left(a^{2} \sigma^{2}\left(r_{i}^{c}\right)+(1-a)^{2} \sigma^{2}\left(r_{m}^{c}\right)\right.\right.} \\
& \left.\left.+2 a(1-a) \sigma^{2}\left(r_{i}^{c}, r_{m}^{c}\right)\right)\right]^{\frac{1}{2}}
\end{aligned}
$$


where $\sigma^{2}\left(r_{i}^{c}, r_{m}^{c}\right)$ denotes the covariance between $r_{i}^{c}$ and $r_{m}^{c}$. By definition, security $i$ is already represented in the market portfolio $m$ according to its market value, and therefore, $a=0$ in equilibrium. Any value greater than zero would mean there is demand for $i$ which is incompatible with the notion of market equilibrium. Since $a=0$ in equilibrium, equation (3) and (4) simplify to $\mu_{Q}=E\left(r_{m}^{c}\right)$ and $\sigma_{Q}=\left[\sigma^{2}\left(r_{m}^{c}\right)\right]^{\frac{1}{2}}$. This shows that the expected return to portfolio $Q$ is the mean return on $c$ 's overall market and the systematic risk of $Q$ is the average deviation of the market return from its mean (Elton et al. 2007, 286-94; Lintner 1965; Sharpe 1964). ${ }^{3}$ Clearly, since $V_{Q}=\gamma \mu_{Q}-\sigma_{Q}$, the value of creating a country portfolio increases if the average return on c's overall market increases. The opposite holds for changes in the standard deviation of the market return, which measures systematic risk. If the average deviation of the return from its mean $\sigma\left(r_{m}^{c}\right)$ increases, the portfolio loses value, which in turn makes capital investment in $c$ 's market less attractive. $^{4}$

Given the importance of a country's market return and standard deviation for the value of capital investments, financial actors should base their capital (re-)allocation decisions on these parameters. Due to changes in one or both of these factors some countries will suffer from investors withdrawing capital from their markets in order to invest this money in the market of another country. Political scientists have devoted great effort to analyzing how politics and political institutions influence the return to a country's financial market (Bernhard and Leblang 2006; Herron 2000; Roberts 1990). However, no study has analyzed the determinants of systematic investment risk as measured by $\sigma\left(r_{m}^{c}\right)$. This lack of scholarly attention is all the more significant since portfolio theory suggests that investors' capital allocation decisions are influenced by how strongly the market return fluctuates around its expected value: if systematic, i.e., nondiversifiable, risk increases, the value of investing in $c$ decreases, which in turn will lead actors to disinvest from a country's financial markets. Such reallocation decisions negatively impact consumption, investment, and growth (Bachman 1992; Demirgüç-Kunt and Levine 1996; Kamara 1997; Levine and Zervos 1998). This paper argues that political factors

\footnotetext{
${ }^{3}$ The model easily generalizes to an arbitrary (finite) number of securities using the same reasoning.

${ }^{4}$ See Elton et al. (2007, 634-48) and Elliott and Kopp (2005) for alternative risk measures.
}

are important determinants of a country's systematic investment risk.

\section{Political Sources of Systematic Risk}

\section{Government Partisanship}

The impact of partisan politics on the economy has traditionally been of interest to scholars of political economy. Since the classic work by Douglas C. Hibbs (1977), one pertinent research question has been whether fluctuations of macroeconomic key variables such as inflation, unemployment, or growth can be explained by changes in government partisanship (Alesina, Roubini, and Cohen 1997). Up until now, scholars have largely ignored the question of whether certain parties are more successful in creating an environment which generates persistently low investment risk.

A notable exception is Fowler (2006) who argues that inflation risk is influenced by the predictability of parties' economic policies. This so called policy uncertainty-as opposed to electoral uncertainty, which is uncertainty about which party will win the upcoming election-arises from "not knowing exactly what economic policies a given party prefers" (Fowler 2006, 92). Evidence from the 2000 U.S. presidential election supports his argument. SantaClara and Valkanov (2003) find that in the United States higher realized returns occur under democratic administrations and term the difference in returns the "Democratic risk premium." They posit that this is due to economic policies of left-leaning governments more strongly deviating from what the market anticipates. The following argument ties in with these valuable first attempts to relate government partisanship and uncertainty on financial markets.

First, preferences of left and right voters differ considerably on economic issues. Voters of right-leaning parties are more likely to be medium- to high-income individuals with a higher propensity to save. As these voters invest a large share of their money, they strongly benefit from market-friendly policies and a stable political environment fostering capital investment. These preferences for market-friendly policies and low policy variance are reflected in parties' economic policies (Budge et al. 2001; Ezrow 2007). Rightleaning parties will try to secure an environment favorable to capital investment by reducing economic 
policy variance, as this benefits high-income individuals who most strongly invest in financial assets. This reduces uncertainty about how the value of capital investment will develop in the future. Therefore, systematic investment risk should be lower during the terms of office of right-leaning governments.

Second, right-leaning parties maintain permanent relationships with industrial associations and firms ("parties of business"). McMenamin and Schoenman (2007) argue that "marriage," which occurs if business interests maintain exclusive relationships with a certain party, is the most attractive type of party-industry relations. Firms can greatly profit from rent seeking by having a party supporting or opposing legislation (Grossman and Helpman 1994) or intervening in bureaucratic decisions (Baron 1989) that matter for their economic performance. Tax, trade, labor, and environmental policies are especially important in this respect. A key aspect of such long-term party-business relationships is that they facilitate the buildup of trust, which decreases the cost of sharing information and thereby promotes the coordination of expectations about future economic policy interventions which affect the performance of financial markets. Such greater predictability adds to reducing systematic capital risk.

Third, left- and right-wing governments differ in their competence to avoid unexpected policy consequences, and in how they react to exogenous economic shocks which are harmful to invested capital. Designing policies which do not have negative side effects is difficult in an increasingly complex world. The risk of economic policy having unexpected consequences or side effects can be strongly reduced if a party receives information about the likely impact of its policies. Firms and industry associations have such knowledge, but it is private information (AustenSmith 1994; Bräuninger and Bernhagen 2005). Longterm cooperation between right-leaning parties and firms makes it easier to successfully and more efficiently engage in information transmission. Therefore, right-leaning parties are better informed about the consequences of economic policies. ${ }^{5}$ Based on such

\footnotetext{
${ }^{5}$ The question may arise why business interests do not provide the same information to left-leaning governments out of simple self-interest. The reason is that such behavior might not be sequentially rational. This is because paying staff, compiling data, and skillfully communicating information to parties in an appealing and customized way causes nonzero costs to business interests. Knowing that left-leaning parties will most likely ignore this information, by way of anticipating this reaction it is rational for business interests not to provide it in the first place.
}

information, right-leaning parties can more clearly assess likely policy effects and are able to more precisely design their policies. Thus, right parties-in contrast to left parties-enjoy an advantage when it comes to avoiding unexpected policy effects. Moreover, given their preference for market friendly policies and their superior knowledge about the consequences of economic policy, right-leaning parties react in a more efficient and beneficial way to exogenous economic shocks, which are harmful to capital investments. This stabilizes investors' expectations about a decisive and efficient policy response by the government in case of an external shock that negatively affects financial markets. In sum, these considerations lead to the following hypothesis:

\section{H1 (Partisan Effect): Right (left)-leaning govern- ments are associated with lower (higher) systematic investment risk.}

A key aspect of research in political economy concerns the impact of government partisanship on inflation. In fact, partisan models of government argue that there should be pronounced differences in inflation across left- and right-leaning governments. For example, Alesina, Roubini, and Cohen (1997) find that leftist administrations are associated with higher inflation than rightist governments. However, since consensus democracies like Germany have strong independent central banks, a relationship between inflation and government partisanship seems less plausible in this institutional context. Hays, Stix, and Freeman (2001) find evidence supporting this argument. ${ }^{6}$ While this makes the analysis somewhat easier-because inflation can hardly be considered to be a function of government partisanship-, it is implausible to assume that the effect of government partisanship on investment risk is independent of changes in inflation. Not only is inflation an important factor for the value of an asset (Elton et al. 2007), since higher inflation decreases the value of capital investments and therefore triggers downward pressure on financial markets. Moreover, since governments are aware of the harmful effect of inflation on capital risk, they will respond (yet differently) to inflation shocks: The stronger inflation changes, the stronger their policy responses. Consequently, one should expect the effect of government partisanship to also be conditional on changes in inflation. This potential relationship will be taken into account in the empirical estimation.

\footnotetext{
${ }^{6}$ Since the introduction of the Euro, monetary policy is of course under the control of the European Central Bank.
} 


\section{Expectations about Government Partisanship}

Actors suffer losses on financial markets if investing in assets which turn out to be less profitable than expected. The incentives to form rational expectations are therefore strong, especially since-as Milton Friedman (1953) notes - "irrational" actors cannot keep losing money forever and will therefore soon or later disappear from the market. Thus, although challenging, it is important to explicitly model rational expectations of government partisanship when analyzing the political determinants of investment risk.

The rational, i.e., expectations-augmented, version of the partisan model posits that prior to an election individuals form expectations which enable them to anticipate the effects of changes in government partisanship (Alesina, Roubini, and Cohen 1997). ${ }^{7}$ To see how expectations about government partisanship influence capital risk, suppose that elections are held at time $e$ and let $\operatorname{Pr}_{t, e}(R)$ denote the probability at time $t$ that a right-leaning party or party coalition will win the upcoming election at $e$. Rational investors should form expectations about future systematic investment risk in country $c$ as the probability weighted sum of the risk levels under different governments. Formally, for a given election date $e$ and assuming away for a moment all other systematic risk factors, rational expectations lead to

$$
\begin{aligned}
\sigma_{t}\left(r_{m}^{c}\right)= & \operatorname{Pr}_{t}(R)\left(\sigma_{t}\left(r_{m}^{c}\right) \mid R\right) \\
& +\left(1-\operatorname{Pr}_{t}(R)\right)\left(\sigma_{t}\left(r_{m}^{c}\right) \mid L\right),
\end{aligned}
$$

where $\sigma_{t}\left(r_{m}^{c}\right) \mid R$ is the level of systematic risk under a right-leaning government and $\sigma_{t}\left(r_{m}^{c}\right) \mid L$ denotes investment risk under a left-leaning government. Notice that equation (5) is simply the sum of the systematic riskiness of c's market under ideologically different governments discounted by the probability of each event, i.e., the electoral prospects of ideologically different governments. Rearranging equation (5) yields

$$
\begin{aligned}
\sigma_{t}\left(r_{m}^{c}\right)= & \left(\sigma_{t}\left(r_{m}^{c}\right) \mid L\right)-\operatorname{Pr}_{t}(R)\left[\left(\sigma_{t}\left(r_{m}^{c}\right) \mid R\right)\right. \\
& \left.-\left(\sigma_{t}\left(r_{m}^{c}\right) \mid L\right)\right] .
\end{aligned}
$$

As right-leaning governments provide policies which reduce systematic risk while left-leaning governments are associated with an increase in systematic risk, the difference in risk levels under different governments,

\footnotetext{
${ }^{7}$ This argument has precedents in both, the finance (Fama 1970) as well as the macroeconomy literature (Lucas 1976).
}

$\left(\sigma_{t}\left(r_{m}^{c}\right) \mid R\right)-\left(\sigma_{t}\left(r_{m}^{c}\right) \mid L\right)$, should be positive. Equation (6) then implies that an increase in the probability of a right-leaning government $\left(\operatorname{Pr}_{t}(R)\right)$ decreases systematic market risk. Rational expectations should thus lead investors to anticipate the effects of government partisanship by being responsive to changes in the probability of different parties holding office. Empirically, if a right-leaning government is becoming more likely to win the upcoming election, one should observe a reduction in systematic capital risk:

H2 (Anticipated Partisan Effect): Systematic investment risk decreases as the probability of a rightleaning government increases.

Taking rational expectations seriously also suggests that electoral uncertainty, conceptualized as the expected closeness of the election outcome, is an important determinant of risk (Fowler 2006; Füss and Bechtel 2008; Herron 2000; Roberts 1990). Increased closeness of the electoral race means that there is higher uncertainty about which government will be installed after the election. As different parties implement different economic policies, higher uncertainty about the electoral outcome increases the probability of an investment deviating from its average value. Such logic leads to the following:

H3 Expected Closeness Effect: Systematic investment risk increases (decreases) as the expected closeness of the electoral outcome increases (decreases).

\section{Coalition Formation}

In political systems which use proportional representation, an additional source of politically induced risk stems from the need to form coalition governments (Lijphart1999). After an election, coalescing parties negotiate over the policies they want to implement and the allocation of ministries (Laver and Shepsle 1996). Policies of multiparty governments therefore represent a bargain between the coalescing parties (Bandyopadhyay and Chatterjee 2006; Martin and Stevenson 2001). In periods of negotiations between potential coalition parties, the final bargaining outcome is difficult to predict. Therefore, Bernhard and Leblang (2006) argue that during periods of coalition formation there is increased uncertainty about the (economic) policies coalition partners will eventually agree on. Thus, even if an election has been held, the subsequent period of coalition formation makes the predictability of future policies difficult.

Empirically, periods of coalition formation often last several weeks - a long time for financial actors. For 
example, after the 2002 German Federal election it took parties three weeks to negotiate a coalition agreement. During these negotiations there was increased uncertainty about the outcome in terms of government policy as well as the allocation of ministries. Consequently, there is a great deal of variance in expectations about which economic conditions will prevail in the future. The empirically observable implication is:

H4 (Coalition Formation Effect): Systematic investment risk is higher during times of coalition formation.

\section{Divided Government and Policy Uncertainty}

Political scientists largely agree that institutions are important for decision-making processes and policy outcomes. A key feature of many democracies is the presence of partisan conflict between the executive and the legislative branches, i.e., divided government. The impact of divided government on law production has been explored extensively (Alesina and Rosenthal 1995; Coleman 1999; Edwards, Barrett, and Peake 1997; Howell et al. 2000; Mayhew 1991). The message of these studies is that divided government either leads to indecisive and incoherent government or gridlock. Researchers have also begun to identify the economic effects of divided government. The evidence suggests that divided government influences trade (Karol 2000; Lohmann and O'Halloran 1994; O'Halloran 1994) and budgetary policies (Alt and Lowry 1994; McCubbins 1991). Poterba (1994), for example, finds that budget deficit reduction in the United States is lower under divided than under unified government.

What can be said about the likely impact of divided government on the predictability of economic policies and thus politically induced investment risk? The theoretical and empirical literature suggests that there are pronounced differences in the possibility (and direction) of policy change under divided and unified government (Krehbiel 1998; Lohmann and O'Halloran 1994). Under unified government an incumbent can unilaterally implement its ideal policy and quickly react to economic shocks, thereby stabilizing market expectations about politically determined investment conditions. This suggests that divided government moderates the effect of government partisanship on systematic investment risk and leads to the following hypothesis:

H5 (Moderating Effect of Divided Government): The effect of government partisanship on systematic investment risk is stronger under unified than under divided government.

\section{Grand Coalition Governments}

In consensus democracies, parties may often be able to form coalition governments which are relatively homogeneous with regard to their ideological positions. Consequently, these coalition governments can still be thought of as either left- or right-leaning. However, sometimes the election result forces parties to form ideologically heterogeneous governments spanning left- as well as right-leaning parties. Obviously, by definition such grand coalition governments are plagued by strong interest heterogeneity, which causes ongoing negotiations about government policy. This makes it difficult to predict politically determined investment conditions. Furthermore, new upcoming issues are very likely to initiate conflict about how these should be addressed in terms of policy. Because of the great distance between parties' ideal policies, the set of possible bargaining outcomes is extremely large. Moreover, enforcement mechanisms between coalition parties are weak. Any coalition party may call into question the negotiated policies, for example, in order to remain visible to their electoral supporters. The result is that grand coalition governments are much less stable than ideologically homogeneous governments, a hypothesis for which Martin and Stevenson (2001) find empirical support. Thus, grand coalition governments are associated with higher uncertainty about which economic policies will be implemented, when this will happen, and how new upcoming issues will be dealt with in terms of policy. This adds to the variance in investors' expectations about the future value of capital investments and suggests the following empirically observable implication:

H6 (Grand Coalition Effect): Grand coalition governments are associated with higher systematic investment risk.

\section{Domestic Political Events}

There are a variety of additional sources of uncertainty in democracies, as the predictability of economic policies can be greatly influenced by single political events. For example, unexpected policy failure or personal impropriety may lead to the replacement of political candidates or the resignation of ministers (Dewan and Myatt 2007). These events are often 
realizations of processes whose final outcome is difficult to predict, which induces investors to speculate about future economic policies. For example, after a call for the resignation of a minister involved in a scandal has been made, it is unclear whether the head of government will eventually choose to fire or to protect her or his minister. In political systems with strong judicial review, additional uncertainty can arise until the supreme court has decided on whether to uphold or overrule a statute which is consequential for investment conditions. According to Fama's (1970) efficient market hypothesis, especially unexpected events affect financial markets in important ways. Unexpected political events are quite common. In Germany, for example, Chancellor Gerhard Schröder surprised the public when he announced his intention to ask for a motion of confidence immediately after the Social Democratic Party had lost a state election in 2005. Therefore, in the empirical estimation special attention will be paid to accounting for a variety of potentially important domestic political events.

\section{Empirical Estimation}

\section{Dependent Variable: Systematic Investment Risk}

As shown in the second section, systematic risk associated with an investment in a country's capital market is given by the standard deviation of the corresponding return to the market portfolio $\sigma\left(r_{m}^{c}\right)$. Let $P_{m, t}^{c}$ denote the price of $c^{\prime}$ 's market index at time $t$, then the market return is

$$
r_{m, t}^{c}=\ln P_{m, t}^{c}-\ln P_{m, t-1}^{c},
$$

and the sample standard deviation of the return is given by

$$
\sigma\left(r_{m, t}^{c}\right)=\left[\frac{1}{T-1} \sum_{\tau=t-T}^{t}\left(r_{m, \tau}^{c}-\bar{r}_{m,(\tau-T, t)}^{c}\right)^{2}\right]^{\frac{1}{2}},
$$

where $\bar{r}_{m,(\tau-T, t)}^{c}$ is the mean return from $t-T$ to $t$ and usually the length of the estimation window $T$ is set to 20. The major German stock index (DAX) is used to represent the market portfolio. The DAX measures the performance of the 30 largest German companies and is one of the world's most regularly quoted market indices. The dependent variable is computed according to equation (8), i.e., systematic investment risk is estimated by the 20-day rolling standard deviations of daily stock returns. ${ }^{8}$

\section{Political Variables}

The empirically observable implications of the theory are evaluated using German data from 1991 to 2005. In order to evaluate the partisan effect hypothesis data were collected on government partisanship distinguishing between left-leaning (reference category), right-leaning, and grand coalition governments. There was no ambiguity in categorizing governments along these lines. Left-leaning governments always consisted of the Social Democratic Party (SDP) and the Greens, which were both located left on the economic left-right dimension. ${ }^{9}$ Rightleaning governments were always formed by the Christian Democratic Union (CDU) and the Liberals (FDP), which both were located to the right of the SDP and the Greens. Party indicates whether a leftleaning (in this case Party $=0$ ) or a right-leaning government $($ Party $=1)$ is installed. Grand coalition governments consisted of a coalition between the two major parties SDP and CDU. The corresponding indicator variable Grand Coalition takes on the value one during times of a grand coalition government and is zero otherwise.

Second Chamber reflects whether the right (CDU) or the left-leaning (SDP) party controls the majority in the Bundesrat, the upper house of the German legislature. This information was taken from Feldkamp and Ströbel (2005). Consequently, the multiplicative term between Second Chamber and

\footnotetext{
${ }^{8}$ Unit root tests reject the null of nonstationarity of the DAX volatility (and return) series. One might object that the sample standard deviation does not always adequately reflect the return variability. A commonly used strategy to "prove" this wrong statement is to construct an increasing (or decreasing) process, e.g., $S_{1}=\{1,2,3,4,5\}$ and compare its standard deviation to another series like $S_{1}=\{3,2,5,1,4\}$. Of course, $S_{2}$ fluctuates much more strongly around its mean than $S_{1}$ (the mean is 3 for both series). Yet, their standard deviation is the same (1.4). The reason why in this case the standard deviation fails to measure the "true" variability lies in the simple fact that the sample mean of a series like $S_{1}$ does not converge (it is trend dominated). This violates the stationarity condition necessary for any consistent estimation. Since the DAX return series is stationary, the sample mean and the sample standard deviation are consistent estimators of the expected mean and the variance.

${ }^{9}$ In contrast to what its name might suggest, the Green party is not a one-issue party, but rather can be considered clearly left on the classic economic left-right dimension (Budge et al. 2001; Debus 2007). This lends scientific support to former Chancellor Helmut Kohl's famous statement about what he took to be the Green party's true nature: "The Green party is like a watermelon, green on the outside and red on the inside."
} 
Party distinguishes between periods of unified and divided government. If both variables are zero (one), this indicates a period of unified government by a left (right)-leaning incumbent.

According to the anticipated partisan effect hypothesis, expectations about government partisanship should be an important preelectoral source of investment risk. In the political economy literature different operationalization strategies have been used. For example, some use a party's vote share from the most recent survey to measure the probability of its victory (Brander 1991). The problem with this measure is that according to the theory investors will not care about public opinion, but rather about who will win the upcoming election. A second alternative is the market model (Herron 2000; Roberts 1990), where bookmakers' odds on elections are employed (Herron 2000, 331). Also, data from political stock markets provide a possible alternative (Fowler 2006). Unfortunately, neither bookmakers' odds on elections nor political stock market data are available. To assess whether investment risk is influenced by expectations about government partisanship prior to elections, electoral probabilities were constructed according to Alesina, Roubini, and Cohen's (1997) electoral option model. While this model acknowledges that public opinion and electoral prospects are not the same, it assumes that government popularity constitutes important information for forming expectations about government partisanship. More formally, at time $t$ the probability of a right-leaning government winning the upcoming election at $e$ is given by

$$
\operatorname{Pr}_{t, e}(\text { Right })=\Phi\left[\frac{\omega_{t}(\text { Right })+\nu(R) d-50}{s(R) \sqrt{d}}\right],
$$

where $\Phi$ is the cumulative standard normal distribution, $\omega$ denotes the proportion of citizens intending to vote for parties forming a right-leaning government at time $t$, and $d$ is the number of days until the election. $\nu$ is the sample mean of daily changes in $R$ 's polled vote shares, and $s(R)$ is the sample standard deviation. Equation (9) provides an estimate of the probability of a right- $\left(\operatorname{Pr}_{t}(\right.$ Right $\left.)\right)$ and left-leaning $\operatorname{Pr}_{t}($ Left $)=1-\operatorname{Pr}_{t}($ Right $)$ government on a certain day $t$. The advantage of this operationalization lies in that it accounts for both the time left until the next election and the variance in polling results. This is necessary because the extent to which investors care about future election results increases the closer the election. In contrast, on the day after an election no investor is interested in which government will be installed several years later. Electoral probabilities reflect this argument by weighting polling results with the time left until the next election. Also, electoral probabilities take into account that changes in polling results are less informative the more volatile they are.

A possible objection concerns the use of the electoral option model within the setting of a multiparty system. Originally, Alesina, Roubini, and Cohen (1997) applied the model to the U.S. party system where electoral competition is dominated by two major parties. In Germany, multiple political parties compete for legislative seats. Therefore, the question is whether one can conceive of coalitions that are about to form in terms of right leaning and left leaning? The answer is twofold. First, in Germany there are also two major parties: The left-leaning Social Democratic Party (SDP) and the right-leaning Christian Democratic Union (CDU). As these two parties dominate party competition, Germany is comparable to the United States insofar as the party system is bipolar (Nohlen 2000, 312). This justifies applying the electoral option model outside a strict two-party system. Second, both small and major parties made explicit and credible coalition promises prior to the elections which took place within the time frame studied: Left (right) parties credibly stated their intention to coalesce with the other left (right) parties. More precisely, the social democrats (SDP) made a commitment to form a left-leaning coalition government with the Greens. The CDU and the Liberals (FDP) announced their willingness to form a right-leaning coalition government if they received the necessary majority.

To evaluate the Electoral Closeness hypothesis an electoral uncertainty measure based on the electoral probabilities was computed (Leblang and Mukherjee 2005). The idea is to define a mapping which reflects that uncertainty $u_{t, e}$ is minimal if the probability of a victory is either very high or very low, and that as the difference in electoral probabilities is becoming smaller, expectations are increasingly uncertain. The functional form is given by

$$
u_{t, e}=1-4\left(\operatorname{Pr}_{t, e}(\text { Right })-0.5\right)^{2},
$$

where $\operatorname{Pr}_{t, e}($ Right $)$ is the probability that $t$ a rightleaning coalition winning the upcoming election on $e$. Equation (10) defines an inverse u-shaped function which equals 1 if the election outcome is very uncertain, i.e., both coalitions win with a probability of 0.5 , and gradually declines to 0 with expectations becoming clearer.

Finally, to evaluate whether coalition formation induces an increase in systematic investment risk, data were collected on coalition formation periods 
following German federal elections from 1991 to 2005. The corresponding indicator variable Coalition Formation equals 1 during times of coalition formation and is 0 otherwise.

A comprehensive set of additional variables accounts for effects of domestic political events on investment risk. Indicator variables were created for riots, strikes, and attacks committed by right-wing extremists. Another set of variables is supposed to pick up influences from unexpected political events and decision processes associated with the early federal election in 2005. In Germany, early federal elections can only take place after the Chancellor loses a vote on a motion of confidence and the German President subsequently decides to dissolve the parliament. Call Vote of Confidence 05 indicates when Chancellor Schröder announced his intention to bring about early elections by forcing his majority in parliament to abstain from the vote on the motion of confidence. Announcement/ Vote Confid 05 equals 1 until the vote on the motion of confidence failed as intended. Decision Elections 05 takes on the value 1 when German President Köhler decided to dissolve the parliament and announced when elections would take place. Finally, Constitutional Complaint 05 picks up uncertainty which arose as two members of parliament filed a constitutional complaint in the Federal Constitutional Court in order to prevent the dissolution of the parliament.

\section{Control Variables}

A number of economic controls and several other event indicator variables are used to further increase confidence in the empirical estimates. Inflation and Interest Rate as well as per capita gross domestic product GDP $p c$ are standard economic controls in empirical finance (Robichek and Cohn 1974; Schwert 1989; Wadhwani 1986). ${ }^{10}$ Inflation is an important variable because according to the net-present value model, higher inflation decreases the value of investment in productive capital, with capital-switching triggering downward pressure on stock prices. Higher interest rates increase the costs of borrowing, which makes investment for companies more expensive. Per

\footnotetext{
${ }^{10}$ These enter log-differenced to ensure stationarity. Stationarity of all variables was tested using Augmented Dickey-Fuller and Phillips-Perron unit-root tests. Another potential problem could be that the independent variables and the dependent variable are cointegrated. A necessary condition for a cointegrating relationship to exist, is that the variables are integrated of order one or higher. However, since the dependent variable is already $I(0)$, cointegration is not an issue here.
}

capita GDP helps to account for changing macroeconomic conditions. ${ }^{11}$

According to conventional wisdom in economics and political economy, investment risk is also greatly influenced by the occurrence of natural disasters (floods, crop failure, hurricanes), exchange rate shocks, and international political events such as onset of war. Consequently, control variables for the occurrence of Natural Disasters (floods, earthquakes), terrorist attacks (Attack WTC 93, Attack WTC 01), the onset of war (Kosovo 99, Afghanistan 99, Iraq 03), and the crisis of the European monetary system in 1992 (EMS Crisis 92) enter the estimations. ${ }^{12}$

Ordinary least squares can be used for the empirical estimation. However, Ljung-Box tests suggest that disturbances of the regression equations are autocorrelated, which means that OLS standard errors will be deflated. There are two possible ways of addressing this problem. One common alternative is to use the Prais-Winsten estimator, which assumes that the residual structure follows an AR (1) process. Given the nature of the dependent variable, this assumption is overly optimistic. A more appropriate alternative is to apply heteroskedasticity and autocorrelation robust (HAC) standard errors, where the maximum lag is the smallest integer greater than or equal to $N^{\frac{1}{4}}$ (Greene 2003, 267). With $N=3593$ observations, this amounts to a maximum lag of 8 . However, to be even more cautious, Newey-West standard errors with a maximum lag of 20 are employed, because the dependent variable is computed from the past 20 return observations.

\section{Results}

Table 1 displays estimation results from several model specifications in which systematic investment risk was regressed on political and economic variables. Turning to the preelectoral factors first, systematic risk decreases if the probability of a right-leaning government increases, as indicated by the significantly negative coefficient (models I and II). This supports the anticipated partisan effect hypothesis.

\footnotetext{
${ }^{11}$ The online appendix at http://journalofpolitics.org/ provides detailed information about the data sources and preestimation unit root tests.

${ }^{12}$ Of course, wars and terrorist attacks are the most extreme manifestations of a polarized political environment. However, since the focus of this paper lies on the impact of domestic politics on investment risk, the effect of onset of war and terrorist attacks are of minor interest to this study. This is why the corresponding variables are merely treated as controls.
} 
Table 1 The Political Sources of Systematic Investment Risk, 1991-2005

\begin{tabular}{|c|c|c|}
\hline & I & II \\
\hline \multicolumn{3}{|l|}{ Preelectoral Factors } \\
\hline $\operatorname{Pr}($ Right $)$ & $-1.799^{* * *}(0.307)$ & $-1.444^{\star \star \star}(0.373)$ \\
\hline Expected Closeness & $0.093(0.237)$ & $-0.125(0.286)$ \\
\hline \multicolumn{3}{|l|}{ Postelectoral Factors } \\
\hline Coalition Formation & $1.201^{\star * *}(0.167)$ & $1.238^{\star \star *}(0.176)$ \\
\hline Party ( 1 = right-leaning) & $-0.753^{* * *}(0.081)$ & $-0.746^{\star * *}(0.081)$ \\
\hline Second Chamber (Party) & $0.257(0.175)$ & $0.199(0.168)$ \\
\hline Party ${ }^{\star}$ Second Chamber & $-1.075^{\star * \star}(0.193)$ & $-1.075^{\star * *}(0.202)$ \\
\hline Party $^{\star}$ Inflation $(\Delta \log )$ & $-0.015(0.651)$ & $-2.748(5.268)$ \\
\hline SecondChamber ${ }^{\star}$ Inflation $(\Delta \log )$ & $-0.824(1.418)$ & $-0.824(1.364)$ \\
\hline Party $^{\star}$ Second Chamber ${ }^{\star}$ Inflation $(\Delta \log )$ & $-0.011(0.651)$ & $0.099(0.178)$ \\
\hline Grand Coalition & $0.830^{\star * \star}(0.180)$ & $0.868^{\star \star \star}(0.190)$ \\
\hline \multicolumn{3}{|l|}{ Political Events } \\
\hline Call Early Elections 05 & & $-0.039^{\star}(0.019)$ \\
\hline Announcement/Vote Confidence 05 & & $-0.723^{\star * *}(0.135)$ \\
\hline Vote of Confidence 05 & & $0.626^{\star * *}(0.140)$ \\
\hline Decision Early Elections 05 & & $-0.623^{\star * *}(0.144)$ \\
\hline Constitutional Complaint 05 & & $-0.444(0.286)$ \\
\hline Riot 92 & & $0.004(0.041)$ \\
\hline Riot 95 & & $0.056(0.051)$ \\
\hline Strike 1995 & & $-0.016(0.039)$ \\
\hline Right-wing Attack & & $-0.255(0.165)$ \\
\hline \multicolumn{3}{|l|}{ Economic Factors } \\
\hline Inflation $(\Delta \log )$ & $-0.446(0.464)$ & $-0.386(0.416)$ \\
\hline Interest rate $(\Delta \log )$ & $0.428(1.325)$ & $1.082(1.338)$ \\
\hline GDP pc $(\Delta \log )$ & $-4.509^{\star}(2.127)$ & $-4.505^{\star}(2.149)$ \\
\hline \multicolumn{3}{|l|}{ Other Events } \\
\hline Natural Disaster & & $0.316(0.333)$ \\
\hline WTC 93 & & $-0.245^{\star \star *}(0.058)$ \\
\hline WTC 01 & & $1.056^{* * *}(0.109)$ \\
\hline Kosovo 99 & & $-0.059(0.175)$ \\
\hline Afghanistan 99 & & $0.203^{\star \star}(0.069)$ \\
\hline Iraq 03 & & $1.842^{\star * \star}(0.146)$ \\
\hline EMS Crisis 92 & & $0.531^{\star * \star}(0.044)$ \\
\hline Constant & $2.327^{\star \star \star}(0.213)$ & $2.356^{\star * \star}(0.220)$ \\
\hline $\mathrm{N}$ & 3593 & 3593 \\
\hline Adj $\mathrm{R}^{2}$ & 0.31 & 0.36 \\
\hline
\end{tabular}

OLS estimates shown with heteroskedasticity and autocorrelation (HAC) robust standard errors in parentheses (lag order $\mathrm{T}=20$ ). ${ }^{*} p<.10,{ }^{* *} p<.05,{ }^{* *} p<.01$.

Market actors seem to incorporate expectations about government partisanship in their current assessment of investment uncertainty. Interestingly, expected closeness does not seem to influence risk in a systematic way.

How do postelectoral factors influence uncertainty on the financial marketplace? In line with the hypothesis, periods of coalition formation are associated with higher investment risk. Holding all else equal, the point estimate suggests that systematic risk is about 1.2 percentage points higher on average when parties negotiate a coalition agreement. In order to empirically assess how government partisanship affects systematic investment risk, it is important to note that all regressions include four multiplicative terms. The first multiplicative term Party ${ }^{*}$ Second Chamber is required in order to evaluate whether the effect of government partisanship is indeed moderated by divided government. The second interaction term Party $^{\star}$ Inflation takes into account the possibility 
that the effect of government partisanship varies depending on changes in inflation. Since Party is interacted with both Second Chamber and Inflation, this creates a tacit two-way interaction between Second Chamber and Inflation and a tacit three-way multiplicative term between Party, Second Chamber, and Inflation (Brambor, Clark, and Golder 2006; Braumoeller 2004).

Although these interaction terms are needed in order to closely evaluate the empirical implications of the theory, they complicate estimation, statistical inference, and interpretation. This is because a noteworthy consequence of including interaction terms is that coefficients of the multiplicative and lower order terms can no longer be interpreted as marginal effects and their standard errors run danger of being useless for hypothesis testing (Brambor, Clark, and Golder 2006). In the present case, the marginal effect of government partisanship is conditional on both, second chamber control and changes in inflation. Thus, in order to estimate the impact of government partisanship on investment risk, the marginal partisan effect was calculated for various value combinations of the two other variables. Also, corresponding confidence intervals were computed from the variance-covariance matrix. Displaying these results graphically greatly facilitates the discussion (Figure 1).

As the black solid line in the upper and middle graph of Figure 1 is always below zero, a right-leaning government (compared to a left-leaning government, which forms the reference category) reduces investment risk on average. However, magnitude and significance of the partisan effect is conditional on changes in inflation and second chamber control. Under unified government (upper graph), right-leaning governments are associated with a significant reduction in systematic risk of 1.8 percentage points on average and holding inflation constant. Since the solid line has a negative slope, the risk-reducing effect of a right-leaning government is stronger, the more positive inflation changes are. For example, under unified government and given a $0.1 \%$ reduction in inflation, a right-leaning government lowers systematic risk by about 1.5 percentage points. But given a $0.1 \%$ increase in inflation, a rightleaning government decreases investment risk by 2 percentage points on average. As suggested by the $95 \%$ confidence interval (dotted lines), these partisan effects are highly significant.

As can be seen from the middle graph of Figure 1, partisan effects are less pronounced under divided government. Changing from a left- to a right-leaning government without second chamber control and holding inflation constant reduces capital risk by
FIGURE 1 The Effect of Government Partisanship on Systematic Investment Risk Conditional on Inflation by Unified/Divided Government
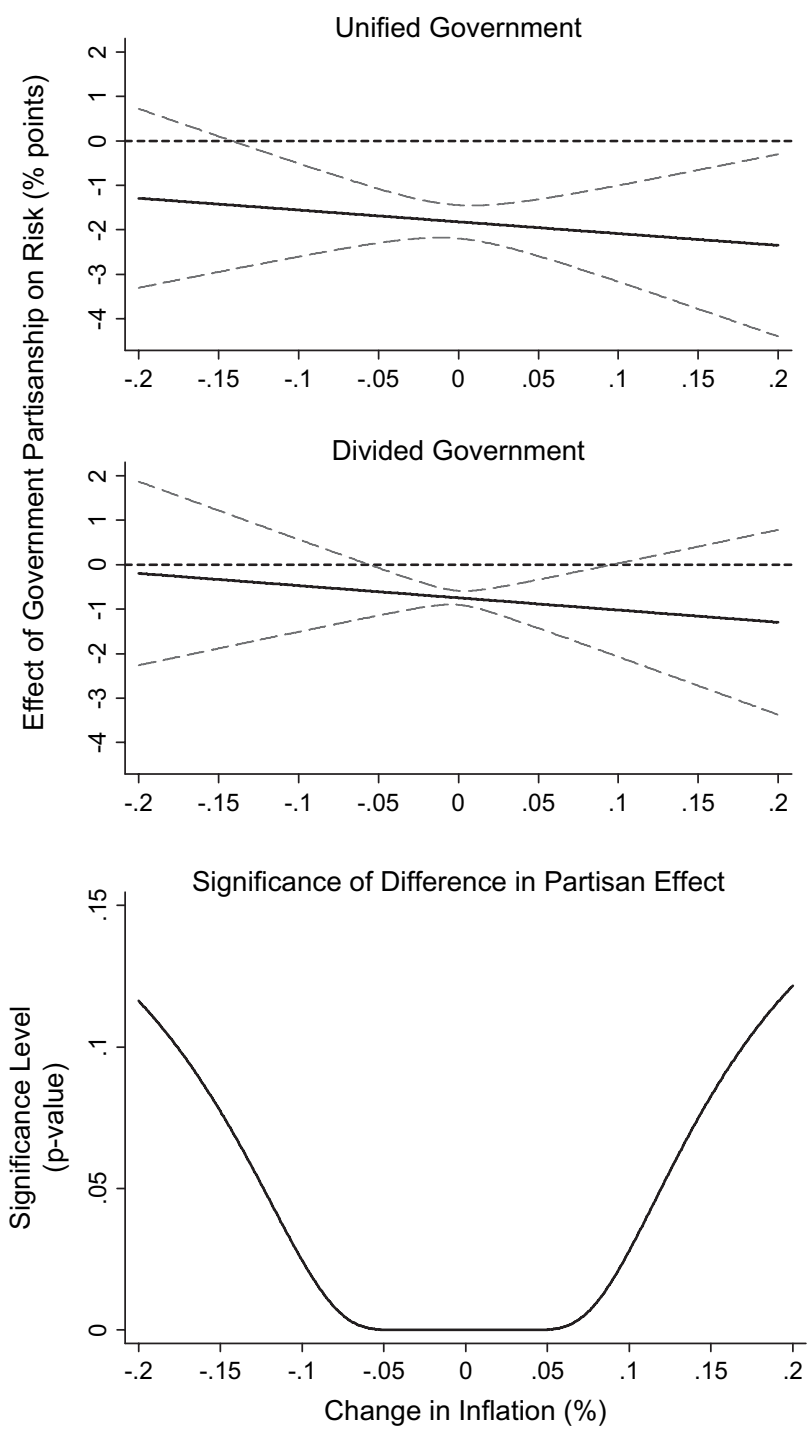

merely about .8 percentage points on average. This suggests that changing from unified to divided government increases investment risk by about one percentage point, thereby watering down the effect of a right-leaning government. For inflation changes farther from zero the partisan effect is no longer significant.

In order to more rigorously evaluate the hypothesis that partisan effects on investment risk are conditional on divided government, the bottom graph of Figure 1 plots the significance level of the difference in partisan effects (DPE). The DPE measures the difference in systematic risk as induced by a change 
from unified to divided government conditional on changes in inflation. Obviously, divided government makes a difference also in statistical terms: for any but very extreme changes in inflation, the DPE is significant at least at a $10 \%$ level. For changes in inflation between -0.1 to $0.1 \%$ DPEs are significant at least at a $5 \%$ level. For inflation changes from -0.06 to $+0.06 \%$ DPEs reach $1 \%$ levels of significance. This supports the view that divided government indeed conditions the effect government partisanship has on systematic investment risk.

Turning back to Table 1, the results also support the idea that grand coalition governments are associated with higher uncertainty about future economic policies. Systematic risk increases by about 0.9 percentage points during times of grand coalition governments. However, domestic political events are important for investment risk as well, as the coefficients clearly suggest. The regression results displayed in the lower panel of Table 1 (model II) also emphasize the need to take into account international political and economic events. The terrorist attacks on September 11 as well as the onset of war in Afghanistan and Iraq increased investment risk. Likewise, the crisis of the European Monetary System in 1992 triggered higher uncertainty on the financial marketplace.

\section{Robustness}

This section presents results from robustness tests. The first question is whether the results are driven by the choice of setting $T$ to 20 . To answer this question, the fully specified model was reestimated with varying lengths of the estimation window. Table 2 presents the results. In model I $T$ is set to 15 . The estimates are very similar to those reported above. The same holds for model II, in which a 30-day estimation window is used.

Second, one might ask whether the estimates are influenced by outliers in the data. To see whether this is the case, the fully specified model was reestimated using robust regression, which iteratively downweights outliers. Thus, if coefficients of interest changed, this would indicate that the slope estimates were indeed influenced by extreme observations. In order to continue accounting for possible heteroskedasticity and autocorrelation in the residuals, HAC robust standard errors are used. However, the estimates are similar to those reported above. An increase in the electoral prospects of a right-leaning government significantly decreases systematic risk, while periods of coalition formation are associated with higher investment uncertainty.
Also with regard to the relevance of postelectoral factors, the picture emerging from the initial estimation results remains unchanged. The coefficient of the interaction term Party ${ }^{*}$ Second Chamber indicates that simultaneously moving from a left-leaning government which controls both chambers to a unified right-leaning government reduces investment risk (holding inflation constant). The conditional partisan effect and the DPEs were recomputed varying inflation under divided and unified government. The estimates remained unchanged and reached even higher significance levels. ${ }^{13}$ In sum, the robustness of these results lend support to the view that politics matter for systematic investment risk.

\section{Conclusion}

Systematic investment risk is important for investors' capital (re-)allocation decisions, which impact consumption, growth, and overall economic performance. This paper argues that several preelectoral, postelectoral, and institutional factors influence systematic risk on financial markets. The results support the argument that right-leaning governments are more successful in providing a tranquil and predictable environment beneficial for capital investment. However, institutions are important as well, since divided government moderates the impact government partisanship has on risk. In addition and in line with rational expectations, the market anticipates partisan effects: In the preelection time systematic risk decreases if a right-leaning government becomes more likely to win the upcoming election and increases if the electoral prospects of a left-leaning government rise. Finally, uncertainty about government policies and the danger of gridlock trigger higher systematic risk during times of coalition formation and grand coalition governments.

The analysis presented extends recent scholarship on the political economy of financial markets and gives rise to several questions which provide impetus for further research. First, the present study focused on the political determinants of systematic investment risk, while others have restricted their analyses to estimating the impact of politics on stock and bond returns (Bernhard and Leblang 2006; Herron 2000; Roberts 1990) as well as on exchange rates (Freeman, Hays, and Stix 2000). These previous

\footnotetext{
${ }^{13}$ The results can be downloaded from the JOP web site.
} 
TABle 2 The Political Sources of Systematic Investment Risk, 1991-2005: Robustness

\begin{tabular}{|c|c|c|c|c|c|}
\hline & \multicolumn{2}{|c|}{ OLS HAC SE } & \multicolumn{3}{|c|}{ IRLS HAC SE } \\
\hline & $\mathrm{T}=15$ & $\mathbf{T}=\mathbf{3 0}$ & $\mathrm{T}=15$ & $\mathrm{~T}=\mathbf{2 0}$ & $\mathrm{T}=\mathbf{3 0}$ \\
\hline \multicolumn{6}{|l|}{ Pre-electoral Factors } \\
\hline $\operatorname{Pr}$ (Right) & $-1.339^{\star * *}(0.349)$ & $-1.526^{* * *}(0.398)$ & $-1.339^{* * *}(0.179)$ & $-1.444^{\star * *}(0.097)$ & $-1.526^{\star \star \star}(0.092)$ \\
\hline Expected Closeness & $-0.198(0.276)$ & $-0.038(0.274)$ & $-0.198(0.087)$ & $-0.125(0.069)$ & $-0.038(0.066)$ \\
\hline \multicolumn{6}{|l|}{ Post-electoral Factors } \\
\hline Coalition Formation & $1.279^{\star \star \star}(0.182)$ & $1.084^{\star \star \star}(0.179)$ & $1.279^{\star \star \star}(0.133)$ & $1.238^{\star \star \star}(0.087)$ & $1.084^{\star \star \star}(0.082)$ \\
\hline Party (1 = right-leaning) & $-0.711^{\star \star \star}(0.070)$ & $-0.752^{\star \star \star}(0.093)$ & $-0.711^{\star \star \star}(0.036)$ & $-0.746^{\star \star \star}(0.024)$ & $-0.752^{\star \star \star}(0.023)$ \\
\hline Second Chamber (Party) & $0.183(0.145)$ & $0.209(0.196)$ & $0.183(0.163)$ & $0.199^{* * \star}(0.032)$ & $0.209(0.030)$ \\
\hline Party ${ }^{\star}$ Second Chamber & $-1.102^{* * *}(0.206)$ & $-0.950^{* * *}(0.208)$ & $-1.102^{\star * *}(0.160)$ & $-1.075^{\star * *}(0.126)$ & $-0.950^{\star * \star}(0.119)$ \\
\hline Party ${ }^{\star}$ Inflation $(\Delta \log )$ & $0.301(0.673)$ & $0.263(0.647)$ & $0.301(0.138)$ & $-2.211(8.291)$ & $-0.263^{\star \star \star}(0.936)$ \\
\hline SecondChamber Inflation $(\Delta \log )$ & $-0.707(1.341)$ & $-0.217(1.239)$ & $-0.707(0.438)$ & $-0.676(1.152)$ & $-0.217(1.902)$ \\
\hline Party ${ }^{\star}$ Second Chamber ${ }^{\star}$ Inflation $(\Delta \log )$ & $-0.590(2.072)$ & $2.266(2.129)$ & $-0.590(0.705)$ & $0.089(0.287)$ & $2.266^{* * *}(0.053)$ \\
\hline Grand Coalition & $0.865^{\star * *}(0.189)$ & $0.812^{\star * \star}(0.187)$ & $0.865^{\star * \star}(0.133)$ & $0.868^{\star * *}(0.157)$ & $0.812^{\star * \star}(0.148)$ \\
\hline \multicolumn{6}{|l|}{ Political Events } \\
\hline Call Early Elections 05 & $-0.040^{\star \star}(0.014)$ & $0.128^{* * *}(0.019)$ & $-0.040^{\star * \star}(0.005)$ & $-0.039(0.558)$ & $0.128(0.528)$ \\
\hline Announcement/Vote Confidence 05 & $-0.698^{\star \star \star}(0.123)$ & $-0.680^{\star * \star}(0.151)$ & $-0.698^{\star * \star}(0.134)$ & $-0.723^{\star * \star}(0.107)$ & $-0.680^{\star \star \star}(0.101)$ \\
\hline Vote of Confidence 05 & $0.553^{\star \star \star}(0.130)$ & $0.611^{\star * *}(0.154)$ & $0.553^{\star * *}(0.133)$ & $0.626(0.578)$ & $0.611(0.546)$ \\
\hline Decision Early Elections 05 & $-0.574^{\star \star \star}(0.134)$ & $-0.632^{\star \star \star}(0.154)$ & $-0.574^{\star \star \star}(0.133)$ & $-0.624^{\star \star \star}(0.149)$ & $-0.631^{\star \star \star}(0.141)$ \\
\hline Constitutional Complaint 05 & $-0.496(0.289)$ & $-0.341(0.280)$ & $-0.491^{\star * \star}(0.121)$ & $-0.440^{\star * *}(0.132)$ & $-0.341^{\star \star}(0.124)$ \\
\hline Riot 92 & $0.020(0.037)$ & $0.129^{\star *}(0.045)$ & $0.020(0.035)$ & $0.004(0.317)$ & $0.129(0.300)$ \\
\hline Riot 95 & $-0.009(0.047)$ & $0.090(0.056)$ & $-0.009(0.026)$ & $0.056(0.317)$ & $0.090^{\star \star}(0.300)$ \\
\hline Strike 1995 & $-0.029(0.036)$ & $0.002(0.044)$ & $-0.029(0.029)$ & $-0.016(0.184)$ & $0.002(0.172)$ \\
\hline Right-wing Attack & $-0.253^{\star}(0.103)$ & $-0.210(0.171)$ & $0.253^{\star * \star}(0.046)$ & $-0.255(0.388)$ & $-0.210^{\star * \star}(0.055)$ \\
\hline \multicolumn{6}{|l|}{ Economic Factors } \\
\hline Inflation $(\Delta \log )$ & $-0.219(0.452)$ & $-0.594(0.486)$ & $-0.219(0.138)$ & $-0.386(0.697)$ & $-0.594^{* \star \star}(0.660)$ \\
\hline Interest rate $(\Delta \log )$ & $0.583(1.455)$ & $0.314(1.075)$ & $0.585(0.552)$ & $1.081(4.126)$ & $0.314(3.899)$ \\
\hline GDP pc $(\Delta \log )$ & $-4.247^{\star}(2.206)$ & $-4.500^{\star}(2.055)$ & $-4.247^{* * *}(0.666)$ & $-4.505^{\star}(1.981)$ & $-4.500^{\star * \star}(1.879)$ \\
\hline \multicolumn{6}{|l|}{ Other Events } \\
\hline Natural Disaster & $0.292(0.282)$ & $0.337(0.359)$ & $0.292(0.235)$ & $0.316^{\star * *}(0.057)$ & $0.337(0.054)$ \\
\hline WTC 93 & $-0.337^{\star \star \star}(0.053)$ & $-0.265^{\star * *}(0.060)$ & $-0.337^{\star * *}(0.046)$ & $-0.245(0.549)$ & $-0.265^{\star * *}(0.519)$ \\
\hline WTC 01 & $1.280^{\star * *}(0.111)$ & $0.618^{* * *}(0.095)$ & $1.280^{\star * *}(0.029)$ & $1.056^{\star * *}(0.195)$ & $0.618^{* * *}(0.184)$ \\
\hline Kosovo 99 & $-0.087(0.151)$ & $0.018(0.171)$ & $-0.087^{\star *}(0.029)$ & $-0.059(0.080)$ & $0.018(0.075)$ \\
\hline
\end{tabular}




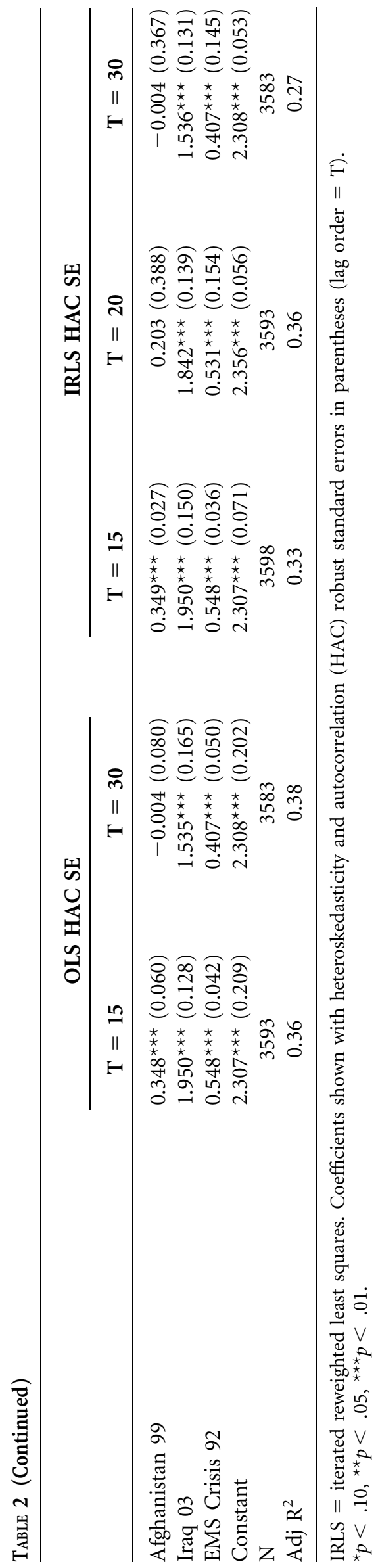

findings and those presented in this article partly diverge, which might be simply due to the fact that their dependent variables were different. Second, and more generally, previous studies may have provided incomplete accounts of the data-generating process underlying the performance of financial markets. As this paper argues, there are various and partly interrelated channels through which political variables affect systematic risk. These factors are likely to be important for returns to other financial assets (e.g., bonds, futures, investment trusts, currencies) as well. Since previous work failed to simultaneously estimate the effects of preelectoral, postelectoral, and institutional factors, political variables relevant to the data-generating process might have been overlooked.

Third, it would be interesting to explore to what extent the partisan effect on investment risk can be traced back to greater variance in parties' economic policies. For example, future research could employ data on parties' ideal policies (e.g., from wordscore analyses or the Comparative Manifesto Project) in order to evaluate whether left-leaning parties change their economic policies more often and more strongly than right-leaning parties. Finally, although the evidence presented in this paper is based on German data and the variance generated within its political system, a considerable part of the theory applies to other countries as well. For example, it seems plausible that in the U.S. policy responses to economic shocks which affect financial markets also depend on both government partisanship and divided government.

The central message of this study is that a variety of political factors, which in part already figure prominently in the political economy literature, are important for investment risk. Since many of these factors do not vary within the United States, the results of this study highlight the need to examine the political sources of systematic investment risk in other countries as well. Only then will scholars be able to get a complete and more fine-grained picture of how democratic politics affects financial markets.

\section{Acknowledgments}

I thank Gerald Schneider and Heinrich Ursprung for very helpful comments. Financial support by the German National Merit Foundation is gratefully acknowledged.

Manuscript submitted 7 January 2008

Manuscript accepted for publication 10 May 2008 


\section{References}

Alesina, Alberto, Nouriel Roubini, and Gerald Cohen. 1997. Political Cycles and the Macroeconomy. Cambridge, MA: MIT Press.

Alesina, Alberto, and Howard Rosenthal. 1995. Partisan Politics, Divided Government, and the Economy. New York: Cambridge University Press.

Alt, James E., and Robert C. Lowry. 1994. "Divided Government, Fiscal Institutions, and Budget Deficits-Evidence from the States." American Political Science Review 88 (4): 811-28.

Austen-Smith, David. 1994. "Strategic Transmission of Costly Information." Econometrica 62 (4): 955-63.

Bachman, Daniel. 1992. "The Effect of Political Risk on the Forward Exchange Rate Bias: The Case of Elections." Journal of International Money and Finance 11 (2): 208-19.

Bandyopadhyay, Siddhartha, and Kalyan Chatterjee. 2006. "Coalition Theory and its Applications: A Survey." Economic Journal 116 (2): 136-55.

Baron, David P. 1989. "Service-Induced Campaign Contributions and the Electoral Equilibrium." Quarterly Journal of Economics 104 (1): 45-72.

Bernhard, William, and David Leblang. 2006. Democratic Processes and Financial Markets: Pricing Politics. Cambridge: Cambridge University Press.

Bernhard, William, and David Leblang. 2002. "Democratic Processes, Political Risk, and Foreign Exchange Markets." American Journal of Political Science 46 (2): 316-33.

Blais, Andre, Donald Blake, and Stephane Dion. 1993. "Do Parties Make a Difference? Parties and the Size of Government in Liberal Democracies." American Journal of Political Science 37 (1): 40-62.

Bräuninger, Thomas, and Patrick Bernhagen. 2005. "Structural Power and Public Policy: A Signaling Model of Business Lobbying in Democratic Capitalism." Political Studies 53 (1): 43-64.

Brambor, Thomas, William R. Clark, and Matthew Golder. 2006. "Understanding Interaction Models: Improving Empirical Analyses." Political Analysis 14 (1): 63-82.

Brander, James A. 1991. "Election Polls, Free Trade, and the Stock Market: Evidence from the 1988 Canadian General Election." Canadian Journal of Economics 24 (4): 827-43.

Braumoeller, Bear. 2004. "Hypothesis Testing and Multiplicative Interaction Terms.” International Organization 58 (4): 807-20.

Budge, Ian, Hans-Dieter Klingemann, Andrea Volkens, Judith Bara, and Eric Tanenbaum. 2001. Mapping Policy Preferences. Estimates for Parties, Electors and Governments 1945-1998. Oxford: Oxford University Press.

Coleman, John J. 1999. "Unified Government, Divided Government, and Party Responsiveness." American Political Science Review 93 (4): 821-35.

Debus, Marc. 2007. Pre-Electoral Alliances, Coalition Rejections, and Multiparty Governments. Baden-Baden: Nomos.

Demirgüç-Kunt, Ash, and Ross Levine. 1996. "Stock Markets, Corporate Finance, and Economic Growth: An Overview." World Bank Economic Review 10 (2): 223-39.

Dewan, Torun, and David P. Maytt. 2007. "Scandal, Protection, and Recovery in the Cabinet." American Political Science Review 101 (1): 63-92.
Edwards, George C. III, Andrew Barrett, and Jeffrey Peake. 1997. "The Legislative Impact of Divided Government." American Journal of Political Science 41 (2): 545-63.

Elliott, Robert J., and Ekkehard P. Kopp. 2005. Mathematics of Financial Markets. 2nd ed. New York: Springer.

Elton, Edwin J., Martin J. Gruber, Stephen J. Brown, and William N. Goetzmann. 2007. Modern Portfolio Theory and Investment Analysis. 7th ed. Hoboken: John Wiley \& Sons.

Ezrow, Lawrence. 2007. "The Variance Matters: How Party Systems Represent the Preferences of Voters." Journal of Politics 69 (1): 182-92.

Fama, Eugene F. 1970. "Efficient Capital Markets: A Review of Theory and Empirical Work." Journal of Finance 25 (2): 383417.

Feldkamp, Michael F., and Birgit Ströbel. 2005. Datenhandbuch zur Geschichte des Deutschen Bundestages 1994 bis 2003. Baden-Baden: Nomos.

Fowler, James. 2006. "Elections and Markets: The Effect of Partisanship, Policy Risk, and Electoral Margins on the Economy." Journal of Politics 68 (1): 89-103.

Friedman, Milton. 1953. Essays in Positive Economics. Chicago: University of Chicago Press.

Füss, Roland, and Michael M. Bechtel. 2008. "Partisan Politics and Stock Market Performance: The Effect of Expected Government Partisanship on Stock Returns in the 2002 German Federal Election." Public Choice 135 (3-4): 131-50.

Freeman, John R., Jude C. Hays, and Helmut Stix. 2000. "Democracy and Markets: The Case of Exchange Rates", in: American Journal of Political Science 44 (3): 449-68.

Greene, William H. 2003. Econometric Analysis. 5th ed. New Jersey: Prentice Hall.

Grossman, Gene M., and Elhanan Helpman. 1994. "Protection for Sale." American Economic Review 54 (4): 833-50.

Hays, Jude C., Helmut Stix, and John R. Freeman. 2001. "The Electoral Information Hypothesis Revisited." http://www. polisci.umn.edu/ freeman/eihr.pdf (March 29, 2007).

Herron, Michael C. 2000. "Estimating the Economic Impact of Political Party Competition in the 1992 British Election." American Journal of Political Science 44 (2): 320-31.

Hibbs, Douglas A. 1977. "Political Parties and Macroeconomic Policy" American Political Science Review 71 (4): 1467-87.

Howell, William, Scott Adler, Charles Cameron, and Charles Riemann. 2000. "Divided Government and the Legislative Productivity of Congress, 1945-94." Legislative Studies Quarterly 25 (2): 285-12.

Kamara, Avraham. 1997. "The Relation between Default-free Interest Rates and Economic Growth is Stronger than You Think." Journal of Finance 52 (4): 1681-94.

Karol, David. 2000. "Divided Government and U.S. Trade Policy: Much Ado about Nothing?" International Organization 54 (4): 825-44.

Knight, Frank H. [1921] 1971. Risk, Uncertainty and Profit. Boston: Hart, Schaffner \& Marx, Houghton Mifflin Company.

Krehbiel, Keith. 1998. Pivotal Politics. A Theory of U.S. Lawmaking. Chicago: University of Chicago Press.

Laver, Michael, and Kenneth A. Shepsle. 1996. Making and Breaking Governments: Cabinets and Legislatures in Parliamentary Democracies. Cambridge: Cambridge University Press.

Leblang, David, and Bumba Mukherjee. 2005. "Government Partisanship, Elections, and the Stock Market: Examining 
American and British Stock Returns." American Journal of Political Science 49 (4): 780-802.

Levine, Ross, and Sara Zervos. 1998. "Stock Markets, Banks, and Economic Growth." American Economic Review 88 (3): 537-58.

Lijphart, Arend. 1999. Patterns of Democracy. Government Forms and Performance in Thirty-Six Countries. New Haven, CT: Yale University Press.

Lintner, John. 1965. "The Valuation of Risk Assets and the Selection of Risky Investments in Stock Portfolios and Capital Budgets." Review of Financial Statistics 47 (1): 13-37.

Lohmann, Susanne, and Sharyn O'Halloran. 1994. "Divided Government and U.S. Trade Policy: Theory and Evidence." International Organization 48 (4): 595-632.

Lucas, Robert. 1976. "Econometric Policy Evaluation: A Critique." Carnegie-Rochester Conference Series on Public Policy 1: 19-46.

Markowitz, Harry M. 1959. Portfolio Selection: Efficient Diversification of Investments. New York: John Wiley \& Sons.

Martin, Lanny W., and Randolph T. Stevenson. 2001. "Government Formation in Parliamentary Democracies." American Journal of Political Science 45 (1): 33-50.

Mayhew, David R. 1991. "Divided Party Control: Does It Make a Difference?” PS: Political Science and Politics 24 (4): 637-40.

McCubbins, Mathew D. 1991. "Government on Lay-Away: Federal Spending and Deficits under Divided Party Control." In The Politics of Divided Government, eds. Gary W. Cox and Samuel Kernell. Boulder, CO: Westview Press, 113-54.

McMenamin, Iain, and Roger Schoenman. 2007. "Together Forever? Explaining Exclusivity in Party-Firm Relations.' Political Studies 55 (1): 153-73.

Mossin, Jan. 1966. "Equilibrium in a Capital Asset Market." Econometrica 34 (4): 768-83.

Mubarak, Ahmed Mushiq. 2005. "Democracy, Volatility, and Economic Development." Review of Economics and Statistics 87 (2): 348-61.

Nohlen, Dieter. 2000. Wahlrecht und Parteiensystem. 4th ed. Opladen, Germany: Leske \& Budrich.
O’Halloran, Sharyn. 1994. Politics, Process, and American Trade Policy. Ann Arbor: University of Michigan Press.

Olson, Mancur. 1993. "Dictatorship, Democracy, and Development." American Political Science Review 87 (3): 567-76.

Poterba, James. 1994. "State Responses to Fiscal Crisis: The Effects of Budgetary Institutions and Policies." Journal of Political Economy 102 (4): 799-821.

Quinn, Dennis P., and John T. Woolley. 2001. "Democracy and National Economic Performance: The Preference for Stability." American Journal of Political Science 45 (3): 634-57.

Roberts, Brian E. 1990. "Political Institutions, Policy Expectations, and the 1980 Election." American Journal of Political Science 34 (2): 289-310.

Robichek, Alexander A., and Richard A. Cohn. 1974. "The Economic Determinants of Systematic Risk." Journal of Finance 29 (2): 439-47.

Roubini, Nouriel, and Jeffrey D. Sachs. 1989. "Political and Economic Determinants of Budget Deficits in the Industrial Democracies." European Economic Review 33 (5): 903-38.

Santa-Clara, Pedro, and Rossen Valkanov. 2003. "The Presidential Puzzle: Political Cycles and the Stock Market." Journal of Finance 58 (5): 1841-72.

Schwert, G. William. 1989. "Why Does Stock Market Volatility Change over Time?" Journal of Finance 44 (5): 623-45.

Sharpe, William F. 1964. "Capital Asset Prices: A Theory of Equilibrium under Conditions of Risk." Journal of Finance 19 (3): 425-42.

Wadhwani, Sushil B. 1986. "Inflation, Bankruptcy, Default Premia and the Stock Market." Economic Journal 96 (381): 120-38.

Michael M. Bechtel is senior researcher at Center for Comparative and International Studies, ETH Zurich (Swiss Federal Institute of Technology), Switzerland. 